\title{
Variation and seasonal patterns of suicide mortality in Finland and Sweden since the 1750s
}

\author{
Jari Holopainen - Samuli Helama \\ Charlotte Björkenstam • Timo Partonen
}

Received: 3 April 2013/Accepted: 13 June 2013/Published online: 9 July 2013

(C) The Japanese Society for Hygiene 2013

\begin{abstract}
Objectives Suicide mortality varies in both the short and long term. Our study examines suicide mortality in Finland and Sweden from the 1750s until today. The aim of our study is to detect any seasonal peaks in suicide rates and examine their temporal evolution to suggest a mechanism that may explain such peaks.

Method We acquired the study material from the Finnish and Swedish cause of death statistics (257,341 deaths by suicide) and the relevant population gender structure data. We then separately calculated the annual male and female suicide rates per 100,000 inhabitants. We analysed the suicide peaks, calculating factors of proportionality for the available data by dividing the suicide rates in the peak months (May and October) by the annual suicide rates.

Results Suicide rates in Finland and Sweden peak twice a year. Both men and women in both countries most often commit suicide in May. There is another peak in October, with the exception of Finnish men. These suicide peaks coincide with a temperature increase in May and the biggest annual drop in temperature in October. We also observed a monotonic long-term change in the Swedish
\end{abstract}

J. Holopainen $(\bowtie)$

Department of Geosciences and Geography,

University of Helsinki, Gustaf Hällströmin Katu 2a,

00014 Helsinki, Finland

e-mail: jari.a.holopainen@helsinki.fi

S. Helama

Finnish Forest Research Institute, Rovaniemi, Finland

C. Björkenstam

Socialstyrelsen, Stockholm, Sweden

T. Partonen

National Institute for Health and Welfare, Helsinki, Finland statistics, but not in the Finnish data. Our hypothesis is that seasonal variation in suicide rates may be caused by abrupt temperature changes twice a year that trigger the activity in brown adipose tissue and deepen depression.

Conclusion While the overall suicide mortality rates varied considerably, the monthly proportions in May did not. This finding suggests a routine factor underlying the spring peak in suicide mortality.

Keywords Population - Season - Suicide rate . Thermal stress · Time

\section{Introduction}

Mortality from suicide varies between latitudes and temperature zones. However, the majority of related studies have recorded a suicide peak between April and June, and some of them confirm another peak in the autumn [1-3]. Nevertheless, some studies have not detected seasonal patterns for suicide mortality $[4,5]$. There is indication that the further from the equator a region is located, the later in the spring the suicide rates peak.

Suicide is not a static and inevitable course of events. Suicide rates vary in both the short and long term [6-8]. Mortality from suicide may additionally vary considerably within a country [9] or in accordance with a section of the population [10]. Suicide is not a minor problem, given all the people who are contemplating suicide, have attempted suicide or are affected, in one way or another, by the suicide of people close to them. Suicide ranks among the ten leading causes of death worldwide [11] and is the second leading cause of death for people aged 15-19 years [12].

In two neighbouring Nordic countries, Finland and Sweden, suicide has been an important public health 
problem. A few decades ago, suicide rates in Finland were among the highest in the world, but since the 1990s they have been decreasing. Still, suicide mortality in Finland has been 1.4-fold greater than the EU average, whereas in Sweden it has been equal to that in recent years [13]. In Sweden the suicide rates have declined since the peak in the early 1970s. However, suicide still constitutes a major public health problem and in an effort to create awareness and to increase knowledge on this phenomenon, the Swedish parliament ratified a zero vision for suicide in 2008 [14].

Recent suicide mortality studies have mainly focused on the past few decades. However, statistical time series covering as long a period as possible are necessary for examining the nature of suicide mortality. Finland and its neighbouring country Sweden have records of demographic change and deaths by suicide since the early $1750 \mathrm{~s}$ $[15,16]$. These are the most extensive continuous demographic statistics available in the world. They enable the year-specific examination of suicide rates over a period of 260 years [17]. Monthly statistics are available from 1861 in Sweden and from 1878 in Finland. Our study examines trends in suicide mortality in Finland and Sweden over the abovementioned time periods. We aim to detect any seasonal peaks in suicide rates and examine their temporal evolution to suggest a mechanism that may explain such peaks.

\section{Methods}

The annual publications of the Finnish and Swedish statistical centres provided the relevant data for determining suicide mortality, including the respective annual suicide rates and national gender structure data. The first Swedish suicide statistics date to 1750 , but the data is discontinuous at first. A uniform time series, including gender data, begins in 1776. Uniform Finnish suicide statistics, including gender data, begin in 1751 . Monthly suicide mortality data is available from 1861 in Sweden and 1878 in Finland.

A database was formed from the suicide data compiled on the basis of the Finnish and Swedish statistical publications. Summary tables of monthly and annual suicide data were then printed out. The monthly and annual suicide rates per 100,000 inhabitants were separately calculated for men and women. Spring (May) and autumn (October) suicide peak variability were analysed by calculating their factors of proportionality. These were calculated by dividing the suicide rates in the peak months (May and October) by the annual suicide rates. We then proceeded to examine the temporal development of the factors of proportionality.

The suicide time series were subsequently analysed using Pearson's product-moment coefficients. Correlations were calculated between the national (Finland versus Sweden) series and between sexes (men versus women). Calculations were performed on annual, seasonal and monthly suicide series.

The suicide time series were clearly autocorrelated. Moreover, it is reasonable to assume that the autocorrelation at different orders was likely to vary from series to series. Consequently, the levels of statistical significance for the resulting Pearson correlations could not be determined using standard options (e.g. tables of statistical textbooks). More appropriate significance levels for the correlations were obtained. To this end, one thousand Monte Carlo simulations were performed [18]. Surrogate data were produced following the frequency-domain method of Ebisuzaki [19]. The discrete Fourier transform was computed for the time series, after which a Fourier series with random phases and the same power spectrum as in the original series was calculated. New synthetic series $(1,000)$ were obtained by the inverse Fourier transform. The empirical probability density functions of each statistic were determined to obtain the corresponding significance based on the resulting two-tailed distribution, and the empirical probability distribution of each statistic was then used to estimate the significance. This procedure was repeated in each correlation calculation. The calculations were run using the algorithms of Macias Fauria et al. [20] and Macias Fauria et al. [21].

In the "Discussion" section, the hypothesis is illustrated with the monthly mean temperatures in Helsinki and Stockholm. The temperature data were mainly downloaded from the Rimfrost databank at http://rimfrost.no/. The Helsinki mean temperature data from 1878 to 1889 were obtained from the KNMI databank at http://climexp.knmi.nl/.

Our research was in accordance with the ethical standards of the institutional and national committees responsible for human experimentation, and with the Helsinki Declaration and its amendments.

\section{Results}

Between 1750 and 2010, a total of 161,182 people committed suicide in Sweden, of whom 119,704 were men and 40,712 were women. A total of 96,159 people committed suicide in Finland between 1751 and 2010, of whom 75,984 were men and 20,175 were women. There has been a general increase in suicide mortality in both countries (Fig. 1). Nevertheless, suicide rates have decreased in both countries in the past few decades. In Sweden, they began to decrease in the 1970s and in Finland in the early 1990s.

Suicide rates repeatedly peak in the spring (May) and in the summer in both countries (Fig. 2). Out of the 92,227 suicides committed in Finland between 1878 and 2010, 

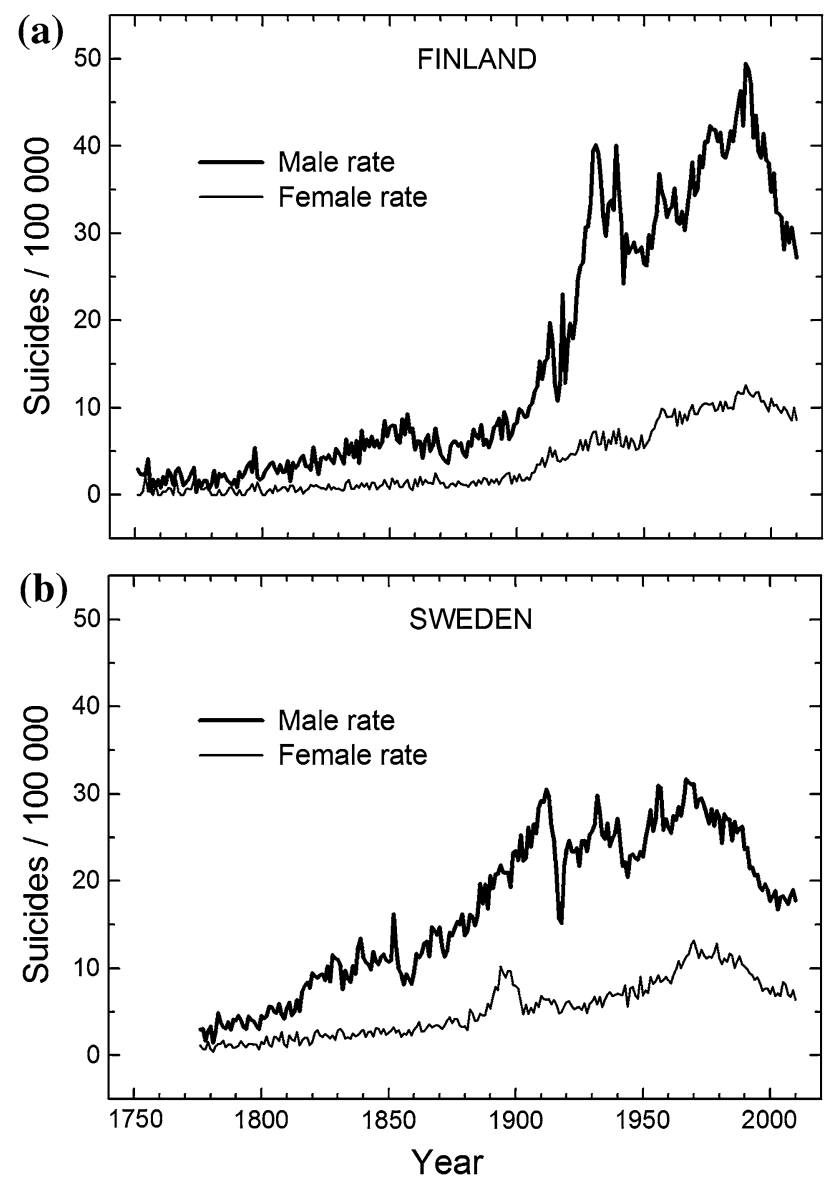

Fig. 1 Suicide mortality rates (per 100,000) by sex in Finland (1751-2010) and Sweden (1750-2010)

$27.0 \%$ were committed in the spring, $27.6 \%$ in the summer, $24.3 \%$ in the autumn and $21.1 \%$ in the winter. Accordingly, out of the 149,186 suicides committed in Sweden between 1861 and 2010, 27.5\% were committed in the spring, $26.8 \%$ in the summer, $24.0 \%$ in the autumn and $21.7 \%$ in the winter.

Regardless of the considerable national variation in monthly suicide rates, similar trends are detectable (Fig. 3). In both countries, men and women alike most often committed suicide in May (Table 1). In both countries, the monthly suicide peak in the autumn occurred in October, with the exception of Finnish men, who also retained a high level of suicide mortality throughout the summer months.

The spring suicide peak for Finnish men and women was highly stable over time (Fig. 4). The Swedish statistics, on the contrary, showed a monotonic, long-term change for both the spring and the autumn peak; however, no changes similar to those in Finland were detected (Fig. 5). Furthermore, the earliest Finnish statistics showed considerable variation in the women's spring peak ratios: in 1878 and 1895, the peak increased by nearly $40 \%$ and
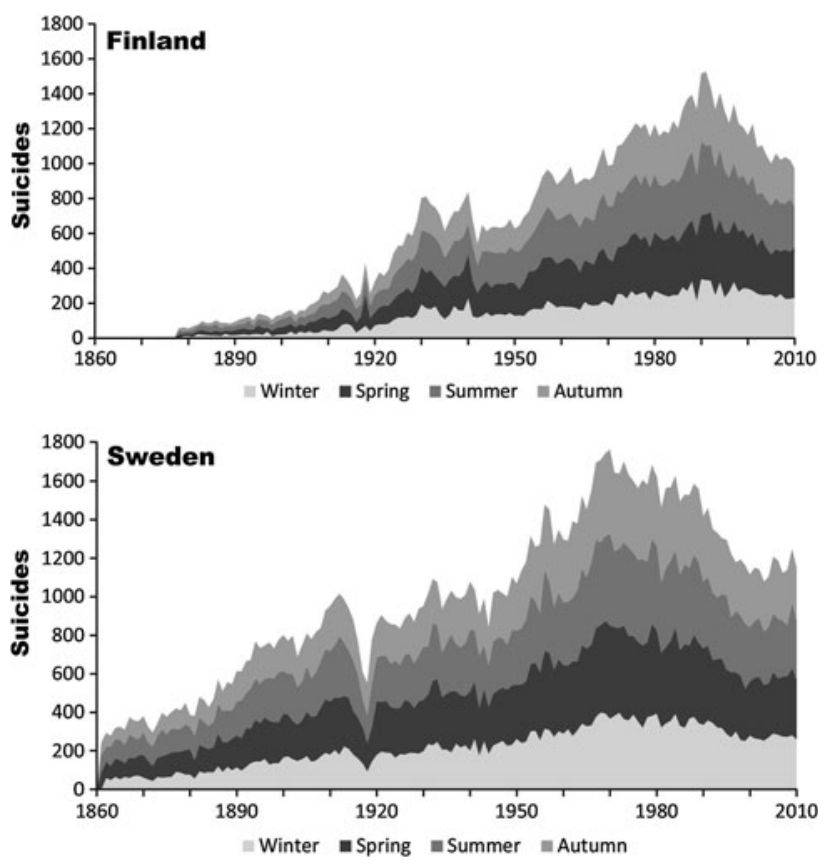

Fig. 2 Seasonal variations in suicides in Finland and Sweden. Winter pertains to the 3-month season from December (previous year) through February, spring to March through May, summer to June through August, and autumn to September through November
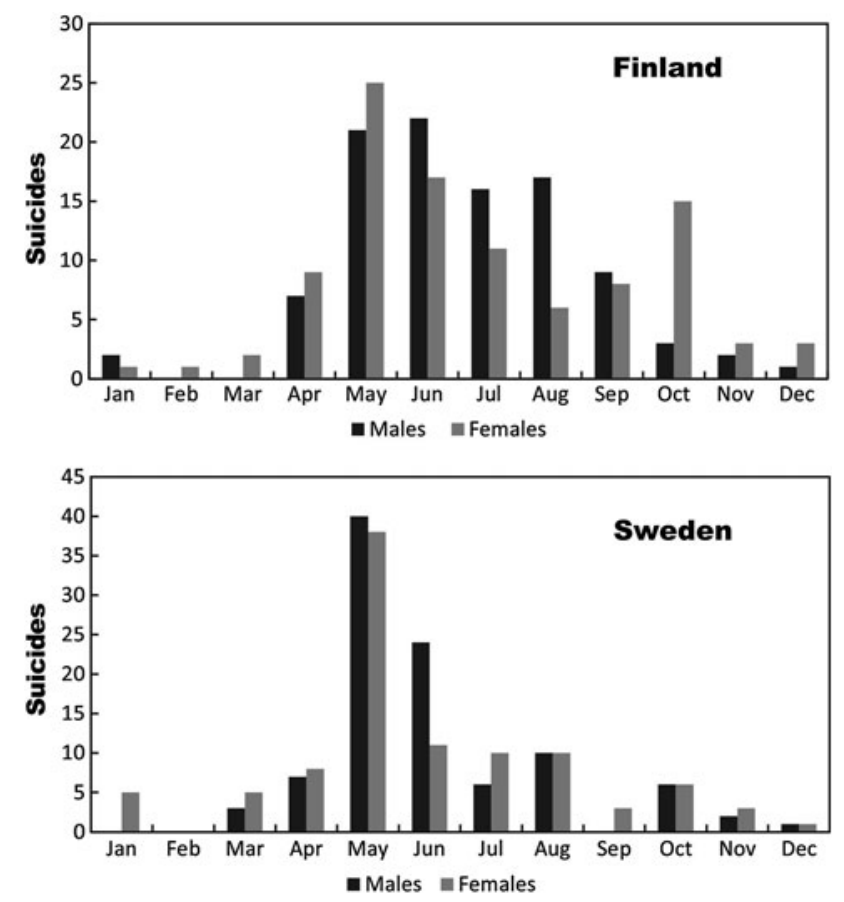

Fig. 3 Distribution of months with highest amount of suicides each year, as presented separately for men and women, in Finland and Sweden during the periods $1878-1935$ and 1969-2010. Each value is the count of years with highest number of suicides during the particular month 
Table 1 Distribution of months with highest amount of suicides each year, as calculated separately for men, women, and total sums, in Finland and Sweden during the periods 1878-1935 and 1969-2010

\begin{tabular}{|c|c|c|c|c|c|}
\hline Men & & Women & & Total & \\
\hline \multicolumn{6}{|l|}{ Finland } \\
\hline January & 2 & January & 1 & January & 1 \\
\hline February & 0 & February & 1 & February & 0 \\
\hline March & 0 & March & 2 & March & 2 \\
\hline April & 7 & April & 9 & April & 4 \\
\hline May & 21 & May & 25 & May & 29 \\
\hline June & 22 & June & 17 & June & 26 \\
\hline July & 16 & July & 11 & July & 14 \\
\hline August & 17 & August & 6 & August & 10 \\
\hline September & 9 & September & 8 & September & 6 \\
\hline October & 3 & October & 15 & October & 4 \\
\hline November & 2 & November & 3 & November & 3 \\
\hline December & 1 & December & 3 & December & 1 \\
\hline \multicolumn{6}{|l|}{ Sweden } \\
\hline January & 0 & January & 5 & January & 0 \\
\hline February & 0 & February & 0 & February & 0 \\
\hline March & 3 & March & 5 & March & 6 \\
\hline April & 7 & April & 8 & April & 10 \\
\hline May & 40 & May & 38 & May & 47 \\
\hline June & 24 & June & 11 & June & 21 \\
\hline July & 6 & July & 10 & July & 4 \\
\hline August & 10 & August & 10 & August & 6 \\
\hline September & 0 & September & 3 & September & 0 \\
\hline October & 6 & October & 6 & October & 7 \\
\hline November & 2 & November & 3 & November & 0 \\
\hline December & 1 & December & 1 & December & 0 \\
\hline
\end{tabular}

Each value is the count of years with highest number of suicides during the particular month

did not decrease in the following years. The Swedish statistics show no similar variation.

The calculated Pearson's correlation coefficients indicated a strong positive correlation between annual Finnish and Swedish male and female suicide rates (Table 2). When comparing the peak months (May and October), we only detected a significant positive correlation between the monthly overall suicide rates of Finnish and Swedish men in the month of May for the period 1878 to 1935. Otherwise, we did not detect a strong positive correlation between the Finnish and Swedish suicide ratios in the peak months (Table 3).

\section{Discussion}

The results indicate that suicide mortality varies considerably in the long term in both Finland and Sweden. Additionally, suicide rates clearly vary according to season
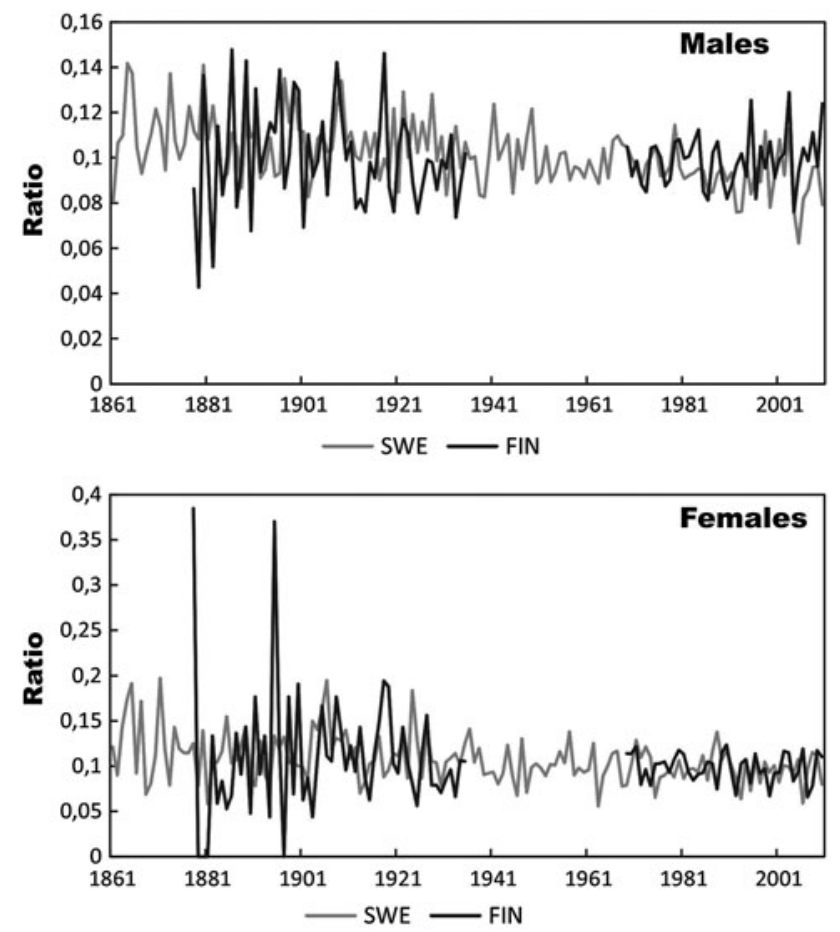

Fig. 4 Temporal variability in spring peak of suicides (May) in Finland and Sweden, 1861-2010
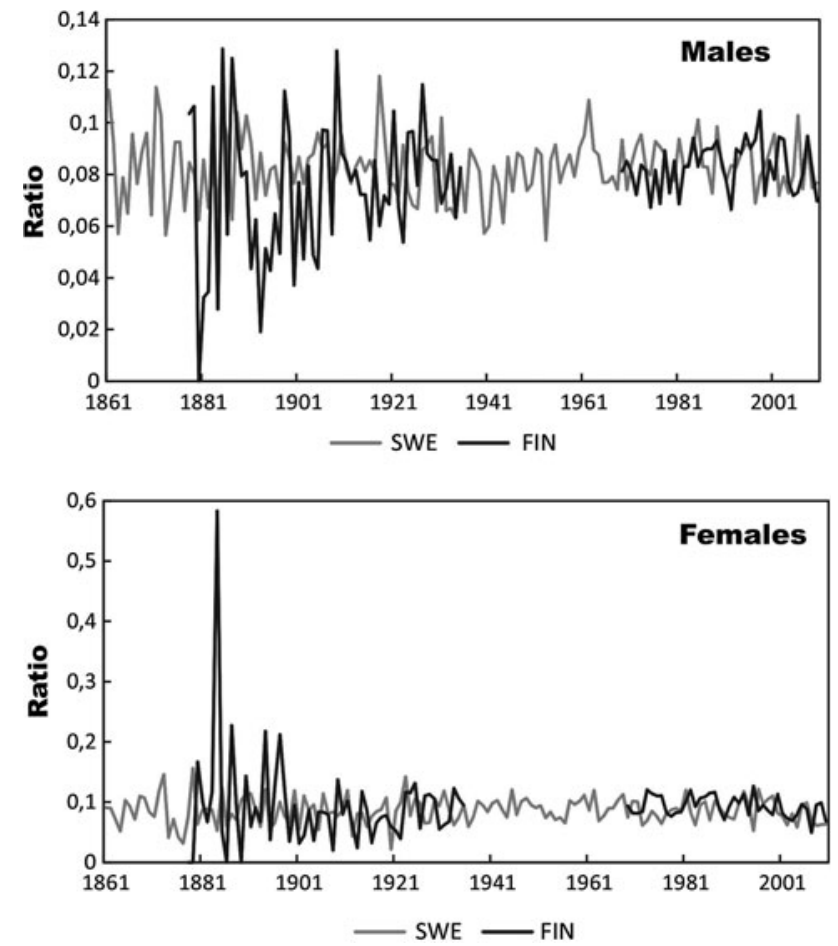

Fig. 5 Temporal variability in autumn peak of suicides (October) in Finland and Sweden, 1861-2010

in both countries. Male and female suicide mortality peaks in May and October in both countries, with the exception of Finnish men. The clear spring peak in male and female 
Table 2 Correlations between Finnish and Swedish suicide sums

\begin{tabular}{|c|c|c|c|c|}
\hline 1776-2010 & S-m-Ann & F-m-Ann & S-f-Ann & F-f-Ann \\
\hline S-m-Ann & 1 & & & \\
\hline F-m-Ann & $0.899(0.0009)$ & 1 & & \\
\hline S-f-Tot & $0.955(<0.001)$ & $0.930(<0.001)$ & 1 & \\
\hline F-f-Tot & $0.879(0.0075)$ & $0.982(<0.001)$ & $0.933(<0.001)$ & 1 \\
\hline 1878-1935 & S-m-May & F-m-May & S-f-May & F-f-May \\
\hline S-m-May & 1 & & & \\
\hline F-m-May & $0.613(0.0392)$ & 1 & & \\
\hline S-f-May & $0.419(0.0757)$ & $0.195(0.4561)$ & 1 & \\
\hline F-f-May & $0.528(0.0841)$ & $0.765(0.0007)$ & $0.247(0.3345)$ & 1 \\
\hline 1969-2010 & S-m-May & F-m-May & S-f-May & F-f-May \\
\hline S-m-May & 1 & & & \\
\hline F-m-May & $0.064(0.9077)$ & 1 & & \\
\hline S-f-May & $0.631(0.0022)$ & $-0.011(0.9837)$ & 1 & \\
\hline F-f-May & $0.040(0.8827)$ & $0.0623(0.7638)$ & $0.002(0.9906)$ & 1 \\
\hline 1878-1935 & S-m-Oct & F-m-Oct & S-f-Oct & F-f-Oct \\
\hline S-m-Oct & 1 & & & \\
\hline F-m-Oct & $0.597(0.0745)$ & 1 & & \\
\hline S-f-Oct & $0.305(0.0543)$ & $0.189(0.3526)$ & 1 & \\
\hline F-f-Oct & $0.429(0.1534)$ & $0.786(<0.001)$ & $0.230(0.1571)$ & 1 \\
\hline 1969-2010 & S-m-Oct & F-m-Oct & S-f-Oct & F-f-Oct \\
\hline S-m-Oct & 1 & & & \\
\hline F-m-Oct & $0.036(0.9602)$ & 1 & & \\
\hline S-f-Oct & $0.464(0.0653)$ & $0.149(0.7894)$ & 1 & \\
\hline F-f-Oct & $0.146(0.7426)$ & $0.476(0.1010)$ & $0.066(0.8229)$ & 1 \\
\hline
\end{tabular}

Pearson correlations were computed between Swedish (S) and Finnish (F) data of males (m) and females (f) using annual (Ann), spring (May) and autumn (Oct) sums over the full period 1776-2010, and over the early (1878-1935) and late (1969-2010) periods common to both national monthly datasets. Statistical significance $(P)$ of each correlation is given in brackets

suicide rates in both countries suggests the influence of a biological factor underlying this routine phenomenon [9].

In both hemispheres, seasonality (pertaining to temperature) increases poleward. Plants, animals and cultures have each adapted to seasonal variation in their own unique ways. That suicide rates in the Northern Hemisphere peak just after the vernal equinox implies that not everyone necessarily adapts to changes in sunlight exposure and temperature with equal ease in the shortest thermal season of the year. Instead, the risk of suicide increases as spring waxes. What mechanism could explain this?

Below we present a new hypothesis for the robust incidence of suicides that peaks during the late-spring and early summer. In mammals, brown fat has a key role in heat and cold tolerance, since in its activated state it generates heat, a phenomenon known as non-shivering thermogenesis. It is current evidence that brown adipose tissue is a highly active tissue, rather than merely being "a form of embryonic adipose tissue" [22] or the so-called hibernating gland, and it is highly prevalent in adult humans [23-25]. It can be activated in nearly all humans, but its activity appears to be reduced in those who are overweight or obese [26, 27].

At temperate latitudes, there are often rapid temperature changes twice a year, during the autumn and during the spring. These changes trigger the metabolic activity in brown adipose tissue. Once brown adipose tissue has become metabolically active, it is more resistant to becoming quiescent [28], and, as we hypothesize, it is then more subject to triggers that are driving it over-activated. It is of note here that non-thermal stimuli, such as the photoperiod, may also affect the development of brown adipose tissue, and that at thermoneutral conditions, equal to room temperature, the inhibitory action of a long photoperiod on the activity of 
Table 3 Correlations between Finnish and Swedish suicide ratios

\begin{tabular}{|c|c|c|c|c|}
\hline 1878-1935 & S-m-May & F-m-May & S-f-May & F-f-May \\
\hline S-m-May & 1 & & & \\
\hline F-m-May & $0.126(0.3096)$ & 1 & & \\
\hline S-f-May & $0.096(0.4983)$ & $0.087(0.4811)$ & 1 & \\
\hline F-f-May & $-0.106(0.3806)$ & $0.214(0.1216)$ & $0.120(0.3234)$ & 1 \\
\hline 1969-2010 & S-m-May & F-m-May & S-f-May & F-f-May \\
\hline S-m-May & 1 & & & \\
\hline F-m-May & $0.135(0.4137)$ & 1 & & \\
\hline S-f-May & $0.150(0.3036)$ & $-0.274(0.664)$ & 1 & \\
\hline F-f-May & $0.294(0.0250)$ & $-0.066(0.6875)$ & $-0.044(0.7566)$ & 1 \\
\hline 1878-1935 & S-m-Oct & F-m-Oct & S-f-Oct & F-f-Oct \\
\hline S-m-Oct & 1 & & & \\
\hline F-m-Oct & $0.170(0.1640)$ & 1 & & \\
\hline S-f-Oct & $0.144(0.2829)$ & $0.114(0.3863)$ & 1 & \\
\hline F-f-Oct & $-0.293(0.0284)$ & $-0.1601(0.1997)$ & $-0.113(0.3886)$ & 1 \\
\hline 1969-2010 & S-m-Oct & F-m-Oct & S-f-Oct & F-f-Oct \\
\hline S-m-Oct & 1 & & & \\
\hline F-m-Oct & $-0.055(0.7362)$ & 1 & & \\
\hline S-f-Oct & $0.096(0.5083)$ & $0.004(0.9789)$ & 1 & \\
\hline F-f-Oct & $0.242(0.1241)$ & $0.076(0.7067)$ & $0.001(0.9985)$ & 1 \\
\hline
\end{tabular}

Pearson correlations were computed between Swedish (S) and Finnish (F) data of males (m) and females (f) using spring (May) and autumn (Oct) ratios over the early (1878-1935) and late (1969-2010) periods common to both national monthly datasets. Statistical significance $(P)$ of each correlation is given in brackets

brown adipose tissue is lost only during the early summer [29], indicating this period of the year to be conducive to over-activation of brown adipose tissue. The mismatch emerging from a conflict between the signals of the photoperiod and those of ambient temperature (i.e. the long and sunny but still cold days at high latitudes during the latespring) might have particular relevance among those suffering from depressive episodes [30]. During depressive episodes of a melancholic type, individuals experience a loss of appetite, insomnia, significant weight loss (e.g. more than $5 \%$ of body weight in a month), and a lack of reactivity to usually pleasurable stimuli. This depressed phenotype matches closely with physiological responses, being produced by over-activation of brown adipose tissue [31].

Currently, there are no direct data on whether the basic activity of brown adipose tissue, or its cold-induced activity, correlate with measures of anxiety or depressive episodes. There are only indirect data demonstrating that those mice with an increased amount of brown adipose tissue but a reduced ability to activate it in response to cold exposure have increased measures of anxiety in behavioural test settings. Concerning humans, there is thus far preliminary evidence that brown adipose tissue was clearly over- activated in two suicide cases involving depressive disorders [32]. However, on the basis of these data it cannot be judged whether the finding concerned only depressed suicide cases or is a key feature of depressive disorder in general. Nevertheless, it gives support to the view that the activation of brown adipose tissue improves cold tolerance at the cost of heat tolerance, triggering anxiety and psychomotor agitation and eventually affecting mood in a negative way during the late-spring and early summer [8].

To illustrate this hypothesis, we compiled a chart of the monthly mean temperatures in the Finnish and Swedish capital cities, Helsinki and Stockholm respectively, from 1878 through to 2010 (Table 4). In that period, February was the coldest and July the hottest month on average in both cities. The greatest changes in monthly mean temperature between two consecutive months were from April to May $\left(+6.0^{\circ} \mathrm{C}\right)$ and from September to October $\left(-5.1^{\circ} \mathrm{C}\right.$ ) in both cities (Fig. 6). The most abrupt changes in the seasonal temperature cycle fully coincide with the spring and autumn suicide peaks. Similarly, the February dip in suicide rates is consistent with the smallest annual change in temperature between two consecutive months, from January to February (approximately $-0.2{ }^{\circ} \mathrm{C}$ ). This 
Table 4 Monthly mean temperatures $\left(T_{\mathrm{c}},{ }^{\circ} \mathrm{C}\right)$ and the temperature differences between the concurrent and previous month $\left(T_{\mathrm{c}}-T_{\mathrm{p}}\right)$, given separately in Helsinki and Stockholm during the period 1878-2010

\begin{tabular}{|c|c|c|c|c|c|c|c|c|c|c|c|c|}
\hline Month & Jan & Feb & Mar & Apr & May & Jun & Jul & Aug & Sep & Oct & Nov & Dec \\
\hline \multicolumn{13}{|l|}{ Helsinki } \\
\hline$T_{\mathrm{c}}$ & -5.1 & -5.8 & -2.7 & 2.8 & 9.2 & 14.3 & 17.3 & 15.9 & 11.2 & 5.9 & 1.2 & -2.7 \\
\hline$T_{\mathrm{c}}-T_{\mathrm{p}}$ & -2.4 & -0.7 & 3.1 & 5.5 & 6.4 & 5.1 & 3.0 & -1.4 & -4.7 & -5.3 & -4.7 & -3.9 \\
\hline \multicolumn{13}{|l|}{ Stockholm } \\
\hline$T_{\mathrm{c}}$ & -2.3 & -2.6 & 0.0 & 4.7 & 10.3 & 15.0 & 17.7 & 16.4 & 12.0 & 7.0 & 2.5 & -0.6 \\
\hline$T_{\mathrm{c}}-T_{\mathrm{p}}$ & -1.7 & -0.3 & 2.6 & 4.7 & 5.6 & 4.7 & 2.7 & -1.3 & -4.4 & -5.0 & -4.5 & -3.1 \\
\hline
\end{tabular}
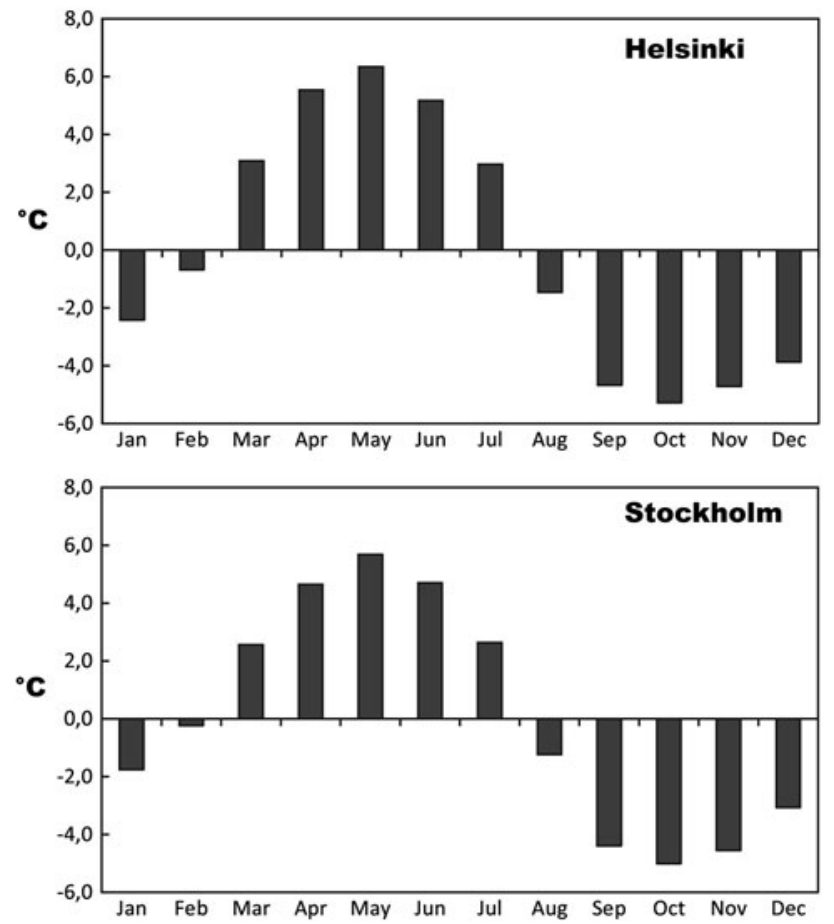

Fig. 6 Temperature difference between two consecutive months in Helsinki and Stockholm. Changes from April to May (referred to as May) and September to October (referred to as October) coincide with the seasonal suicide maximums in May and October

comparison reinforces the view that most suicides are committed in the months of greatest variation in temperature and that suicide rates are at their lowest in the months of least variation in temperature.

The strong positive correlation between the overall annual suicide rates in Finland and Sweden indicates that suicides were committed in the same period of the year in both countries over the long period examined in this study. National differences in monthly suicide peaks can most likely be explained by a constantly varying factor (or factors) which had a less pronounced effect in Finland than it did in Sweden over the study period. A particular weatherrelated or social change, for example, a northward shift in the population, could constitute such factor. It is important to bear in mind that Finland and Sweden were part of the same country from the start of the time series until 1809 . Furthermore, despite the countries' joint land border in the north, one-third of Swedish terrain is located further south than the southernmost parts of Finland. Consequently, a particular climatic development may partially explain the national differences in suicide peak month trends.

We did not find a clear explanation for the abrupt variation in the spring suicide peak in Finland in the late 1800s. However, it may have resulted from a change in the prevalence of suicide committed by young women (ages 20-24 years) in connection with unwanted pregnancy [33]. Then again, the abrupt changes may also be a coincidence. The number of female suicides in May in the late 1800s generally varied from 0 to 3 . However, five women committed suicide in May 1878 (out of an annual overall of 13 female suicides) and 10 women committed suicide in May 1895 (out of an annual overall of 27 female suicides). In comparison, on average, 26 women have committed suicide in May over the past 10 years (2001-2010).

Changes in behaviour leading to suicide may be an indication of the direct influence of biological factors or of the significance of social factors in suicide. What is clear is that suicide rates have increased in the long term. For example, in Finland, there were 2 suicides in $1756(0.43$ per 100,000) and 1,523 in 1990 (30.47 per 100,000), demonstrating a 70 -fold increase in suicide mortality in 234 years. Thereafter, by 2010 , suicide mortality rates per 100,000 inhabitants had decreased in both countries, to 17.75 in Finland and 12.05 in Sweden. The fact that suicide rates do not vary abruptly in both countries simultaneously is probably an indication of the nature of the prevalence of suicide as a personal solution within a specific cultural and temporal framework [16]. Globally speaking, the nature of suicide may vary considerably between nations and in the long term.

Our study contains certain limitations. First, this study employs an operational definition of suicide: any death classified as suicide on a death certificate is treated as suicide. Our study did not address issues concerning unclear cause of death, or how the cause was determined or who determined it. Second, the Finnish statistics do not 
specify gender for the months from 1936 to 1968. A third potential limitation in this respective of this study originates from the assumption of linearity. Pearson correlation measures the linear dependence between the two records; therefore, other methods, targeted to reveal non-linear dependences [34], might be used to overcome this limitation. However, non-linear dependences were beyond the scope of this study.

Preventing suicide remains a challenge for both societies. Our results encourage studies on the seasonal interaction of brown fat functions and temperature variations. Such studies may pave a way to identify a target on which interventions may have a therapeutic effect, thus providing help in prevention of deaths from suicide during the spring peaks of excessive suicide mortality.

Acknowledgments The algorithms of Macias Fauria et al. [16] and Macias-Fauria et al. [17] can be downloaded via http://www.helsinki. fi/science/dendro/reconstats.html. We thank Tauno Tyllinen, Irmeli Penttilä, Johan Hulth and Birgitta Chisena for their help during the data compilation. The work of $\mathrm{JH}$ was supported by the Kone Foundation (post-doctoral grant to $\mathrm{JH}$ ) and the work of $\mathrm{SH}$ by the Academy of Finland (251441).

Conflict of interest The authors declare they have no conflict of interest.

\section{References}

1. Kevan S. Perspective on season of suicide: a review. Soc Sci Med. 1980;14:369-87.

2. Chew KSY, McCleary R. The spring peak in suicides: a crossnational analysis. Soc Sci Med. 1995;40:223-30.

3. Christodoulou C, Douzenis A, Papadopoulos FC, et al. Suicide and seasonality. Acta Psychiatr Scand. 2012;125(2):127-46.

4. Yip PS, Chao A, Chiou CW. Seasonal variation in suicides: diminish or vanish. Experience from England and Wales. Br J Psychiatry. 2000;177:366-9.

5. Ajdacic-Gross V, Bopp M, Sansossio R, et al. Diversity and change in suicide seasonality over 125 years. J Epidemiol Commun Health. 2005;59:967-72.

6. La Vecchia C, Lucchini F, Levi F. Worldwide trends in suicide mortality, 1955-1989. Acta Psychiatr Scand. 1994;90:53-64.

7. Levi F, La Vecchia C, Lucchini F, et al. Trends in mortality from suicide, 1965-99. Acta Psychiatr Scand. 2003;108:341-9.

8. Hiltunen L, Suominen K, Lönnqvist J, et al. Relationship between daylength and suicide in Finland. J Circadian Rhythms. 2011;9:10. doi:10.1186/1740-3391-9-10.

9. Partonen T, Haukka H, Lönnqvist J. Itsemurhakuolleisuus Suomessa vuosina 1979-2001. Duodecim. 2003;119:1827-34.

10. Mäki NE, Martikainen PT. Socioeconomic differences in suicide mortality by sex in Finland in 1971-2000: a register-based study of trends, levels, and life expectancy differences. Scand J Public Health. 2007;35:387-95.

11. Hawton K, van Heeringen K. Suicide. Lancet. 2009;373:1372-81.

12. WHO (World Health Organization). Suicide prevention (SUPRE). http://www.who.int/mental_health/prevention/suicide/suicide prevent/en/index.html (Accessed 1 Jun 2013).
13. Official Statistics of Finland. Causes of death 2011. http:// tilastokeskus.fi/ti1/ksyyt/2011/ksyyt_2011_2012-12-21_en.pdf (Accessed 1 Jun 2013).

14. Socialstyrelsen. Causes of death 2011. http://www.socialsty relsen.se/Lists/Artikelkatalog/Attachments/19001/2013-2-30.pdf (Accessed 1 Jun 2013).

15. Beskow J, Allebeck P, Wasserman D, et al., editors. Självmord i Sverige. En epidemiologisk översikt. Stockholm: Medicinska forskningsrådet; 1993.

16. Holopainen J, Helama S, Partonen T. Memes and Finnish suicide. J Soc Med. 2010;47:174-86.

17. Nieminen M. 250 years of population statistics: a review on the history of population statistics 1749-1999. Vantaa: Tummavuoren Kirjapaino; 1999.

18. Efron B, Tibshirani R. Bootstrap methods for standard errors, confidence intervals, and other measures of statistical accuracy. Stat Sci. 1986;1:54-75.

19. Ebisuzaki W. A method to estimate the statistical significance of a correlation when the data are serially correlated. J Clim. 1997; 10:2147-53.

20. Macias Fauria M, Grinsted A, Helama S, Moore J, Timonen M, Martma T, Isaksson E, Eronen M. Unprecedented low twentieth century winter sea ice extent in the Western Nordic Seas since A.D. 1200. Clim Dyn. 2010;34:781-95.

21. Macias-Fauria M, Grinsted A, Helama S, Holopainen J. Persistence matters: estimation of the statistical significance of paleoclimatic reconstruction statistics from autocorrelated time series. Dendrochronologia. 2012;30(2):179-87.

22. Sheldon EF. The so-called hibernating gland in mammals: a form of adipose tissue. Anat Rec. 1924;28:331-47.

23. Cypess AM, Lehman S, Williams $\mathrm{G}$, et al. Identification and importance of brown adipose tissue in adult humans. $\mathrm{N}$ Engl $\mathrm{J}$ Med. 2009;360:1509-17.

24. Virtanen KA, Lidell ME, Orava J, et al. Functional brown adipose tissue in healthy adults. N Engl J Med. 2009;360(15):1518-25.

25. Lee P, Greenfield JR, Ho KK, Fulham MJ. A critical appraisal of the prevalence and metabolic significance of brown adipose tissue in adult humans. Am J Physiol Endocrinol Metab. 2010;299: E601-6.

26. van Marken Lichtenbelt WD, Vanhommerig JW, Smulders NM, et al. Cold-activated brown adipose tissue in healthy men. $\mathrm{N}$ Engl J Med. 2009;360:1500-8.

27. Enerbäck S. Human brown adipose tissue. Cell Metab. 2010; 11:248-52.

28. Zukotynski KA, Fahey FH, Laffin S, et al. Seasonal variation in the effect of constant ambient temperature of $24^{\circ} \mathrm{C}$ in reducing FDG uptake by brown adipose tissue in children. Eur J Nucl Med Mol Imaging. 2010;37:1854-60.

29. Heldmaier G, Steinlechner S, Rafael J, et al. Photoperiodic control and effects of melatonin on nonshivering thermogenesis and brown adipose tissue. Science. 1981;212:917-9.

30. Partonen T, Haukka J, Pirkola S, et al. Time patterns and seasonal mismatch in suicide. Acta Psychiatr Scand. 2004;109:110-5.

31. Wallberg-Henriksson H, Zierath JR. A new twist on brown fat metabolism. Cell. 2009;137:22-4.

32. Huttunen P, Kortelainen ML. Long-term alcohol consumption and brown adipose tissue in man. Eur J Appl Physiol. 1990; 60:418-24.

33. Saarimäki P. The norms, practices and conflicts of sex and marriage - Premarital and marital sexual activity in rural Central Finland in the late nineteenth century. Jyväskylä: Jyväskylä University Printing House; 2010.

34. Čenys A, Lasiene G, Pyragas K. Estimation of interrelation between chaotic observables. Physica. 1991;D52:332-7. 